\title{
The application of novel methods of Animal Barrier Screen and Kelambu Trap for mosquitoe's surveillance in South and West Sulawesi, Indonesia
}

\author{
NUR RAHMA ${ }^{1, \boldsymbol{v}}$, HAJAR HASAN ${ }^{2}$, ARINI RATNASARI ${ }^{1}$, ISRA WAHID ${ }^{2, v \vee}$ \\ ${ }^{1}$ Graduate School, Faculty of Medicine, Universitas Hasanuddin. Jl Perintis Kemerdekaan Km. 10, Makassar 902425, Indonesia \\ Tel./fax.: +62-411-586010, Fax.: +62-21-39832018, `email: nurrahma5571@gmail.com \\ ${ }^{2}$ Faculty of Medicine, Universitas Hasanuddin. Jl Perintis Kemerdekaan Km. 10, Makassar 902425, Indonesia. Tel./fax.: +62-411-586010, Fax.: +62-21- \\ 39832018, "*email: israwahid@gmail.com
}

Manuscript received: 16 August 2020. Revision accepted: 24 September 2020

\begin{abstract}
Rahma N, Hasan H, Ratnasari A, Wahid I. 2020. The application of novel methods of Animal Barrier Screen and Kelambu Trap for mosquitoe's surveillance in South and West Sulawesi, Indonesia. Biodiversitas 21: 4787-4794. Mosquito's surveillance requires effective protocols to catch mosquitoes in a large number of species and individuals while safe for humans. The effectiveness of two novel trap methods was compared during dry and wet seasons in rural (Maros), semi-urban (North Toraja) both in South Sulawesi Province, and rural with coastal areas (Pasangkayu) in West Sulawesi Province. Animal Barrier Screen (ABS) is a barrier screen placed near livestock, while Kelambu Trap (KT) is an innovative form of mosquito net. Both trap innovations showed effective in catching mosquitoes, but $\mathrm{ABS}$ was more effective in trapping the mosquitos (8,589 individuals) than $\mathrm{KT}$ (8,350 individuals). In contrast, the species caught were more diverse in KT (43 species, nine genera) than that in ABS (36 species, seven genera). During the wet season, ABS and KT caught 4,848 individuals (27 species, five genera) and 4,749 individuals (36 species, eight species), respectively. Mosquitoes were the most abundant in Northern Toraja (6,338 individuals), followed by in Maros (5,566 individuals) then Pasangkayu (5,035 individuals), but mosquito diversity was the highest in Pasangkayu (nine genera, 33 species) compared to that in Northern Toraja (six genera, 27 species) and Maros (five genera, 25 species). Based on the effectiveness of this trap, innovative insecticide can be added into ABS and KT traps then placed in the field. The number of mosquitoes can be significantly reduced so that it can also lower the potential spread of the mosquitoes-born viruses.
\end{abstract}

Keywords: Animal Barrier Screen, diversity, Kelambu Trap, mosquitoes, season

\section{INTRODUCTION}

An understanding of arbovirus, virus that is transmitted by arthropods (Contigiani et al. 2017), requires information about the interactions between arboviruses, arthropod vectors, and vertebrate hosts. Arthropod vectors appear to actively enhance immune and antiviral responses to arbovirus infection which can substantially change the pattern of arbovirus transmission (Huang et al. 2019). Mosquitoes as arbovirus vectors can transmit viruses, such as West Nile virus (WNV), Usutu virus (USUV), Dengue virus (DENV), Japanese encephalitis virus (JEV), Zika virus (ZIKV), Chikungunya virus (CHIKV), and Rift Valley fever virus (RVFV) (Schulz and Becker 2018). The increasing effect caused by these viruses is a neurological disease that is now present throughout the world (David and Tyler 2016).

Mosquitoes acquire viruses from infected hosts and then transmit them to other hosts through saliva (inoculating infected saliva) (Contigiani et al. 2017). Mosquitoes have high physiological adaptability to exist in diverse ranges of habitat. Mosquitoes can also exist periodically or permanently in ecosystems, both in clean water and filthy water, and they are able to occupy in large and small areas (Becker et al. 2010).
Research on arbovirus-carrying mosquitoes requires surveillance of mosquito acting as a vector. Many factors need to be considered for the surveillance, such as climate or mosquito season, host preference, activity pattern, biting time, and resting behavior (Becker et al. 2010). Surveillance of adult mosquitoes can be performed using Human Landing Catches (HLC) as a gold-standard method to catch anthropophilic mosquitoes (Tangena et al. 2015); however, the procedure is complicated and it can transmit the disease to the volunteer (Service 1977), hence rises ethical concern. Therefore, an alternative method to catch mosquitoes using a no-human trap is needed.

Some of the traps commonly used to catch mosquitoes include light traps (LT) which are capable to capture Anopheles arabiensis in South Central Ethiopia on a large scale indoors and monitoring the mosquitoes which cannot be done in HLC (Kenea et al. 2017). However, this method is difficult to be placed in the field because it requires electricity. Animal Bited Tent (ABT) is an untreated net placed near the livestock. These traps have been used in trapping Anopheles malaria vectors in Jayapura District, Papua Province, Indonesia (Laurent et al. 2016). Mosquito can be trapped inside but only through the two sides of the net, making the chance for trapped is less effective. BG sentinel is trap that uses attractants so that it can be 
modified according to effectiveness and needs. These traps have the potential for sampling of malaria vector mosquitoes in Africa with representative host physiological conditions (Batista et al. 2018) but it is not sufficient to see the diversity of mosquitoes in the field. Another trap is barrier screen that was used in Indonesia and Solomon Island that is effective and representative as temporary resting place trap and host-seeking exophilic mosquitoes (Burkot et al. 2013).

Here, we introduce innovative no-human traps for collecting adult mosquitoes, i.e. Animal Barrier Screen (ABS) and Kelambu Trap (KT). ABS is a modified barrier screen that is placed near to the livestock so that the resting and animal blood-feeding mosquitoes can be caught. KT is a modified bed net that has four sides for mosquitoes to enter, so that the chances of mosquitoes being trapped are greater than ABT. This trap is placed between the settlement and the breeding site. This trap is developed by our laboratory at the Department Parasitology, Faculty of Medicine, Hasanuddin University used for collecting adult mosquitoes in both dry and wet seasons.

\section{MATERIALS AND METHODS}

\section{Study area}

Mosquito surveillance was performed in three districts located in the provinces of South Sulawesi and West Sulawesi to explore the richness of mosquito in the area that was endemic for malaria and dengue. The three locations were Pucak (Maros District), Tallunglipu village (North Toraja District), and Pasangkayu town (Pasangkayu District) (Figure 1). The former two are located in South Sulawesi, while the later is in West Sulawesi. Pucak has a botanical garden with inhabitants mostly as farmers. It is surrounded by rice fields and forests and represented a rural ecosystem. Tallunglipu village is a semi-urban area, with many rice fields. Most farmers in this village are women since its young men are usually going to work in other provinces, such as Papua and Kalimantan, and hence contributed to the imported malaria from their endemic working places. Pasangkayu is a new town situated along the coastal line of North Mamuju, West Sulawesi, and it was developed in previously forested areas and is nowadays surrounded by oil palm plantations. Most of the inhabitants are people from outside of the province that come to open forest for plantation area.

\section{Trap description}

Mosquito traps used in this study were Animal Barrier Screen (ABS) and Kelambu Trap (KT) (Figure 2). ABS is a modified barrier screen (Burkot et al. 2013) that is placed near livestock (i.e. cattle, goat, or pig), which will attract mosquito and rest on the screen surface. It is made of a fabric with 10-15 m length and $2 \mathrm{~m}$ height (Davidson et al. 2019). The KT is an innovative form of a bed net with size of $4 \times 4 \times 2 \mathrm{~m}$, has four entrances instead of one, in each of its sides has an internal diagonal partition that divides the space inside into four triangle-shaped rooms. As the ABS, the $\mathrm{KT}$ is a no-human trap made from fabric with no attractant inside. It is placed at an open space and designed for trap free flying/hovering mosquitoes due to its large dimension. Mosquitoes can easily get in through the side entrances but difficult to get out (Davidson et al. 2019).

\section{Mosquito sampling}

Sampling in Pucak, Pasangkayu, and Tallunglipu were carried out in dry season in July, August, and September 2018, respectively, and for the wet season was conducted in October, November, and December 2018, respectively.

Kelambu Traps (KT) was placed between settlements, while Animal Barrier Screen (ABS) were placed between human settlement and breeding sites with the livestock was placed about 2 meters away from the screen. The livestock in Pucak and Pasangkayu was cattle, while ABS in Toraja used pigs. The traps were placed in the afternoon, and the arrests were taken from $18.00-06.00$ with the arrest of fifteen minutes every hour. Mosquitoes were captured using an aspirator and then placed in paper cups. Mosquitoes were identified using the $\mathrm{O}$ 'Connor and Supanto (1996) key books.
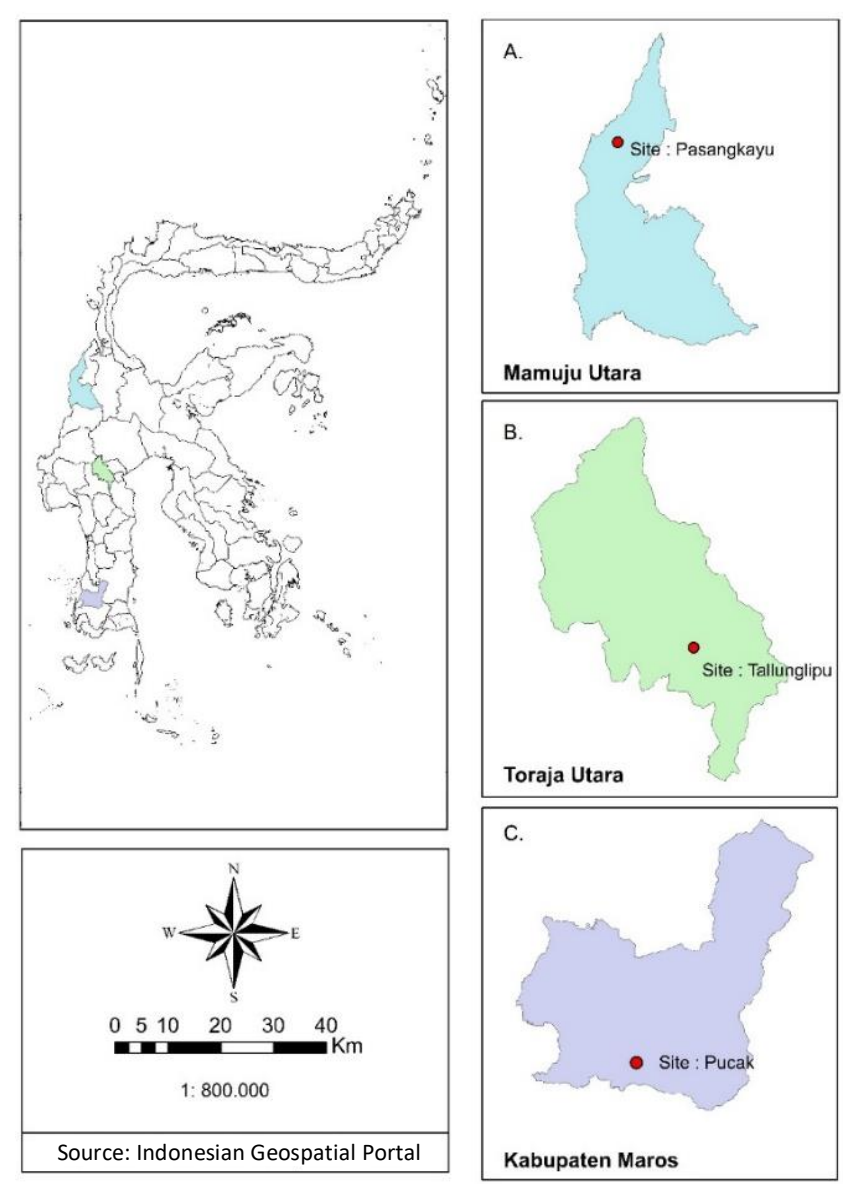

Figure 1. Map of the sampling locations in South and West Sulawesi, Indonesia: A. Pasangkayu, North Mamuju; B. Tallunglipu, North Toraja; C. Pucak, Maros 


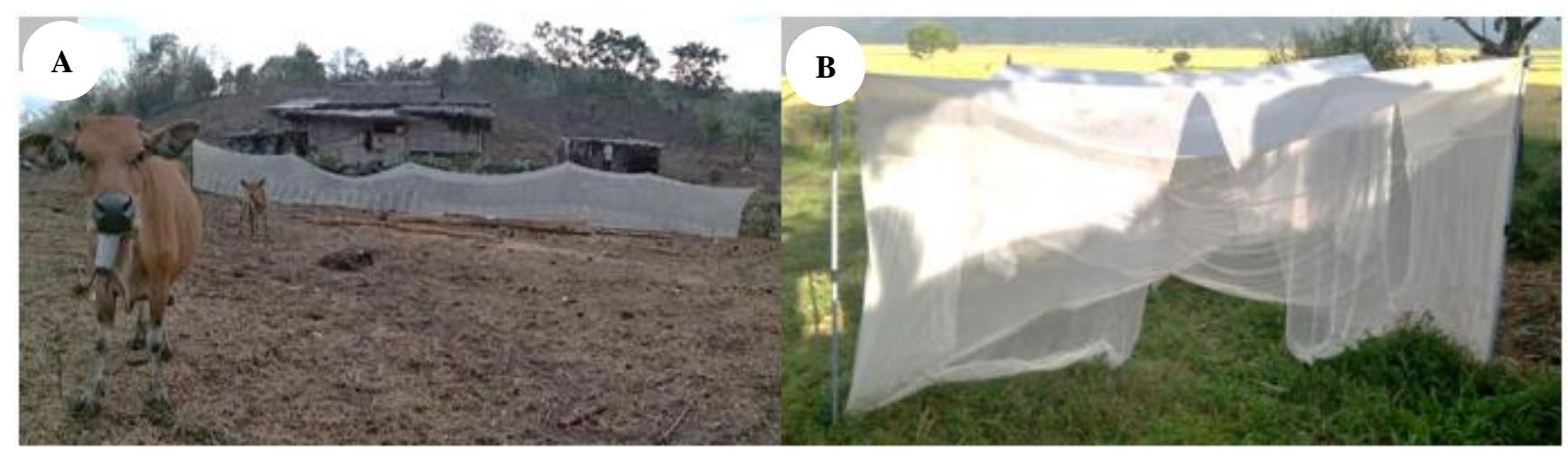

Figure 2. Mosquito traps used in this study: A. Animal Barrier Screen, B. Kelambu Trap

\section{Data analysis}

Data will be presented in tables and diagrams. The index used was species diversity (Shannon-Wiener), dominance (Simpson), species richness (Margalef), and evenness (Magurran 1988). The formula from each index is as follows:

Species diversity index (Shannon-Wiener)

$\mathrm{ID}=\mathrm{H}^{\prime}=-\sum P i \ln P i$, where $P i=\mathrm{ni} / \mathrm{N}$

Species richness indices (Margalef's Diversity index)

$\mathrm{D} M g=(\mathrm{S}-1) / \ln \mathrm{N}$

Evenness index

$\mathrm{E}=\mathrm{H}^{\prime} / \mathrm{H} \max$

Dominance index (Simpson's index)

$\mathrm{D}=\sum P i^{\wedge} 2$

Whereas:

H' : Shannon-Wiener diversity index

DMg: Margalef's Diversity index

E : Evenness index

D : Simpsons index

ni : the number of individuals of each species

$\mathrm{N}$ : the total number of all species

$P i \quad$ : abundance index

$\mathrm{S} \quad$ : number of species

Data processing used Microsoft Excel and SPSS version 18.

\section{RESULTS AND DISCUSSION}

There was a total of 16,939 mosquitoes collected during the study period from the three study sites in the wet and dry seasons: i.e. 5566, 6338, and 5035 from Maros, North Toraja, and Pasangkayu districts, respectively. They were 25 species ( 5 genera), 27 species (6 genera), and 33 species (8 genera) identified from the respected districts, as shown in Table 1 and Figure 3. The number of mosquitoes collected was 7329 (7 genera, 34 species) and 9610 (8 genera, 34 species) from the dry and wet season, respectively (Table 2).

Anopheles was the genus with the most diverse species from the study sites: An. argyropus, An. barbirostris, An. barbumrosus, An. flavirostris, An. kochi, An. maculatus, An. minimus, An. nigerrimus, An. peditaeniatus, An. subpictus, An. sulawesi, An. sundaicus, An. tesselatus, and $A n$. vagus. Culex was the second richest species: $C x$. bitaeniorhynchus, $C x$. fuscocepalus, $C x$. gelidus, $C x$. hutchinshoni, Cx. infula, Cx. longicornis, Cx. malayi, Cx. minimus, $C x$. nigropunctatus, $C x$. sitiens, $C x$. tritaeniorhynchus, $C x$. vishnui and $C x$. whitmorei. Aedes had eight species: Ae aegypti, Ae. albopictus, Ae. butleri, Ae. dux, Ae. flavipennis, Ae. linneatopennis, Ae. sp, Ae. vexans and Ae. vigilax. Armigeres and Lutzia each had two species: Ar. malayi, Ar. subalbatus, Lz. fuscana and $L z$. vorax. Other genera had only one species: Coquillettidia crassipes, Mansonia uniformis, Mimomyia aurea, and Uranotaenia sp.. The "Others" group is the combined data of Armigeres, Coquillettidia, Lutzia, Mansonia, Mimomya, and Uranotaenia.

The most abundant mosquito in the three locations was Culex with the highest in North Toraja (4719 individuals from 11 species). Most Anopheles were found in Maros (1934 individuals from 10 species), while Aedes were mostly found in Pasangkayu (1056 from 8 species). Other species were mostly found in Pasangkayu (21 individuals from 5 genera and 6 species).

Mosquito species diversity was higher in areas with a high variety of ecosystems that serve as mosquito breeding places. It is shown that the traps placed in Pasangkayu, which is a rural area with coastal lines, were able to traps of 8 genera (Culex, Aedes Anopheles, Armigeres, Mansonia, Mimomyia, Coquillettidia, and Uranotenia) and 33 species. The area consisted of many habitats, such as forest, swamp, river, mangroves, rice fields, and containers around the settlement. The traps in North Toraja, which is a semi-urban area with rice fields, bamboo, and containers, consisted of six genera (Culex, Aedes, Anopheles, Armigeres, Mansonia, and Lutzia) and 27 species. The traps in Maros, which is an urban area with very wide rice field, farm, and river ecosystem, only consisted of five genera (Culex, Aedes, Anopheles, Armigeres, and Lutzia) and 25 species. 

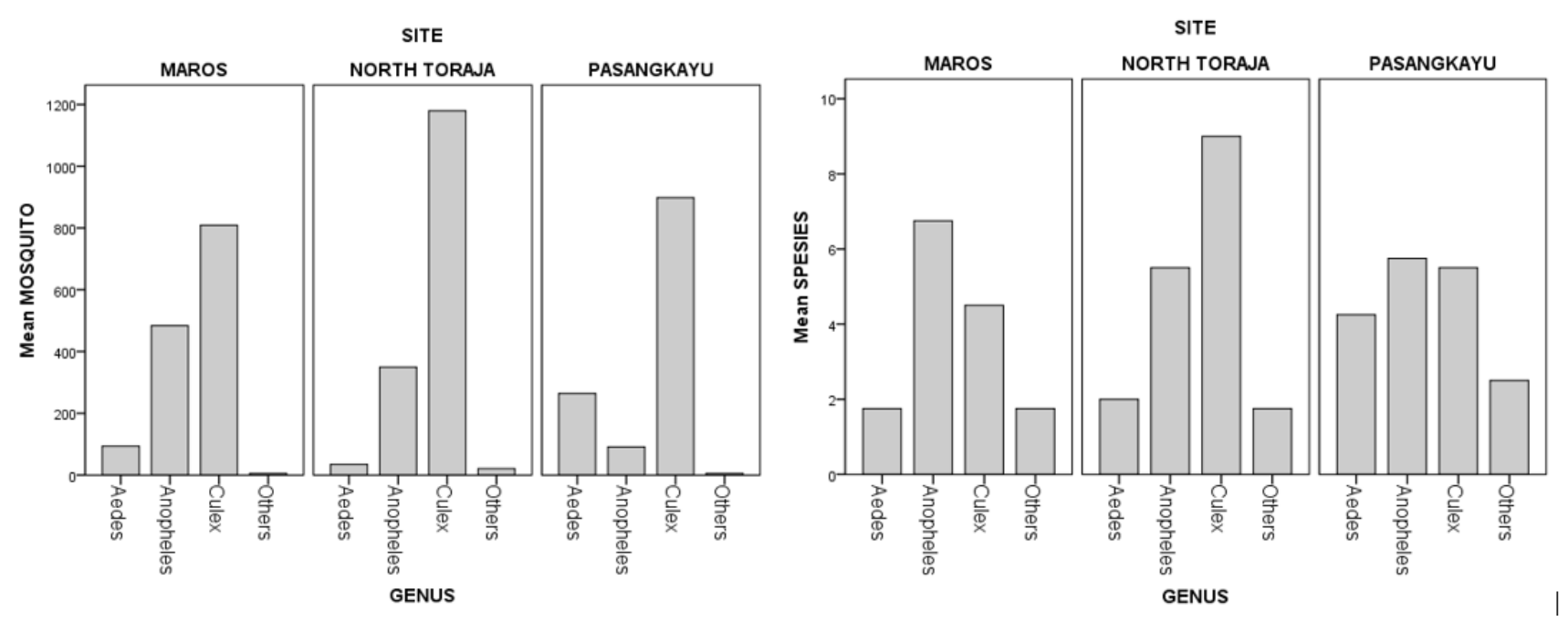

Figure 3. Proportion of the number of individual mosquitoes (left) and number of species (right) for each site

Table 1. Number of species and individual of mosquitos collected from the three study sites

\begin{tabular}{|c|c|c|c|c|c|c|c|c|c|}
\hline \multirow[b]{2}{*}{ Genus } & \multicolumn{3}{|c|}{ Maros } & \multicolumn{3}{|c|}{ North Toraja } & \multicolumn{3}{|c|}{ Pasangkayu } \\
\hline & $\begin{array}{c}\text { No. } \\
\text { species }\end{array}$ & $\begin{array}{c}\text { No. } \\
\text { individual }\end{array}$ & $\%$ genus & $\begin{array}{c}\text { No. } \\
\text { species }\end{array}$ & $\begin{array}{c}\text { No. } \\
\text { individual }\end{array}$ & $\begin{array}{c}\% \\
\text { genus }\end{array}$ & $\begin{array}{c}\text { No. } \\
\text { species }\end{array}$ & $\begin{array}{c}\text { No. } \\
\text { individual }\end{array}$ & $\begin{array}{c}\% \\
\text { genus }\end{array}$ \\
\hline Aedes & 4 & 375 & 6.74 & 5 & 138 & 2.18 & 8 & 1056 & 20.97 \\
\hline Anopheles & 10 & 1934 & 34.75 & 8 & 1398 & 22.06 & 12 & 365 & 7.25 \\
\hline Armigeres & 1 & 17 & 0.31 & 1 & 2 & 0.03 & 2 & 8 & 0.16 \\
\hline Coquillettidia & 0 & 0 & 0.00 & 0 & 0 & 0.00 & 1 & 1 & 0.02 \\
\hline Culex & 8 & 3236 & 58.14 & 11 & 4719 & 74.46 & 7 & 3593 & 71.36 \\
\hline Lutzia & 2 & 4 & 0.07 & 1 & 66 & 1.04 & 0 & 0 & 0.00 \\
\hline Mansonia & 0 & 0 & 0.00 & 1 & 15 & 0.24 & 1 & 9 & 0.18 \\
\hline Mimomya & 0 & 0 & 0.00 & 0 & 0 & 0.00 & 1 & 2 & 0.04 \\
\hline Uranotaenia & 0 & 0 & 0.00 & 0 & 0 & 0.00 & 1 & 1 & 0.02 \\
\hline & 25 & 5566 & & 27 & 6338 & & 33 & 5035 & \\
\hline
\end{tabular}

Table 2. Number of species and individual of mosquitos in each season

\begin{tabular}{|c|c|c|c|c|c|c|}
\hline \multirow{2}{*}{ Genus } & \multicolumn{3}{|c|}{ Dry season } & \multicolumn{3}{|c|}{ Wet season } \\
\hline & No. species & No. individual & $\%$ genus & No. species & No. individual & $\%$ genus \\
\hline Aedes & 5 & 389 & 5.31 & 7 & 1180 & 12.28 \\
\hline Anopheles & 13 & 1655 & 22.58 & 10 & 2042 & 21.25 \\
\hline Armigeres & 2 & 21 & 0.29 & 1 & 6 & 0.06 \\
\hline Coquillettidia & 0 & 0 & 0.00 & 1 & 1 & 0.01 \\
\hline Culex & 11 & 5199 & 70.94 & 11 & 6349 & 66.07 \\
\hline Lutzia & 1 & 46 & 0.63 & 2 & 24 & 0.25 \\
\hline Mansonia & 1 & 17 & 0.23 & 1 & 7 & 0.07 \\
\hline Mimomyia & 1 & 2 & 0.03 & 0 & 0 & 0.00 \\
\hline \multirow[t]{2}{*}{ Uranotaenia } & 0 & 0 & 0.00 & 1 & 1 & 0.01 \\
\hline & 34 & 7329 & & 34 & 9610 & \\
\hline
\end{tabular}

The abundance of mosquitoes was high in area with a large extent of rice fields such as in North Toraja (6338) and Maros (5566) compared to Pasangkayu (5035). Rice field can be great breeding sites for Culex and Anopheles throughout the wet season, and it resulted in a high abundance of both mosquitoes. Culex was the genus with the highest abundance in the three study sites. The highest species was $C x$. tritaeniorhynchus, which is a vector of Japanese encephalitis in Surabaya, Indonesia (Widiarti et al. 2014). Culex can breed in many places and various habitats and this trait caused research locations that had swamp areas (Maros, Pasangkayu), rice fields (Maros, North Toraja), and coastal areas (Pasangkayu) as potential breeding sites for this species. Culex larvae can survive either in clean or polluted water and in various types of breeding sites, such as standing water, gutters, tire molds, pond, and footprints (Nchoutpouen et al. 2019). The abundance of Culex mosquitoes has the potential of risk for 
the spread of Japanese encephalitis (Lindahl et al. 2012), zika (Huang et al. 2016), Usutu, and West Nile (Fros et al. 2015). The presence of swine (North Toraja), buffalo (North Toraja), and bovine (Maros, Pasangkayu) at the research sites further increased the chances of the virus transmission process since these animals could serve as reservoirs for mosquitoes' life and for transmitting diseases (Huang et al. 2019).

The second-highest number of mosquitoes in Maros and North Toraja was Anopheles. Anopheles can breed in both rivers and soil (Nurdin et al. 2003), and this caused Anopheles to remain abundant in the wet season $(21.25 \%)$ and the dry season (22.58\%). Anopheles larvae can be found in various waterways, puddles, and ponds (Inunggita et al. 2019), also found in the same place with Culex larvae (Nchoutpouen et al. 2019), thus Anopheles was also abundant in place with many Culex breeding sites, such as Maros and North Toraja. The presence of Anopheles has a high risk of transmitting malaria, especially in high cases of migration to malaria-endemic areas (Sibala 2013), including the Toraja and Pasangkayu region. Malaria cases in North Toraja are increasing, and this likely caused by the presence of the malaria vector and the high number of migrations from Papua. An. barbirostris has been confirmed as a vector of malaria in two villages in Mamuju, where other supporting factors are the presence of transmigrants from Java, Lombok, Bali, and other districts in South Sulawesi (Nurdin et al. 2003).

Aedes had higher abundance in Pasangkayu (1056) compared to Maros (375) and North Toraja (138), especially Ae. vexan (2.68\%). Aedes can adapt in urban areas so they can survive even though there is no forest as their natural habitat (Lwande et al. 2020) like conditions in Pasangkayu. Aedes larvae can be found in unused tires, containers filled with water, plants (Philbert et al. 2013), and mud pots (Ferede et al. 2018). The larvae prefer containers around housing, although they can also be found in brackish water in suburban areas (Ramasamy et al. 2011). The habitats around human settlement can be filled with water in the wet season, whereas in the dry season, mangroves and swamps area the potential breeding sites for the Aedes. Aedes is the vector for many arboviruses, such as dengue, chikungunya, yellow fever, and zika.

The data analysis shows that the number of species of mosquitoes in Pasangkayu was very high (33 species, 5035 individuals) then followed by North Toraja (27 species, 6338 individuals) and Maros (25 species, 5566 individuals), so that the species richness index is also the highest in Pasangkayu $(\mathrm{D} M g=3.75)$ then North Toraja $(\mathrm{D} M g=2.97)$ and Maros $(\mathrm{D} M g=2.78)$.

Pasangkayu had the highest diversity of species, indicated with the highest of diversity and evenness indices $(\mathrm{H}=2.01, \mathrm{E}=0.58)$ and the lowest dominance index $(\mathrm{D}=$ 0.2). This is in accordance with Soegianto (1994) which stated that a community has high species diversity if composed of many species with the same or nearly the same of its abundance. The area with the lowest species diversity was Maros $(\mathrm{H}=1.45)$, although the dominance index was slightly below North Toraja. This means that North Toraja had the highest species concentration, but
Maros had a lower species evenness $(E=0.45)$. This result is in accordance with Magurran (1988) that the dominance and the unequal distribution of species cause the smaller evenness of species. The low prevalence and number resulted in low diversity in this area $(\mathrm{H}=1.45)$ (Figure 4.).

The mosquitoes caught during the dry season and the rainy season had the same number of species, but more mosquito individuals were trapped in the dry season. Culex and Anopheles were more prevalent in the dry season (70.94\% and $22.58 \%$, respectively) than the wet season (66.07\% and $21.25 \%$ respectively), whereas Aedes was more prevalent in the wet season $(12.28 \%)$ than the dry season $(5.31 \%)$ (Figure 5).

There are differences in the abundance of individual and species Culex in the three locations, where in Pasangkayu and Maros, Culex was abundant in the wet season while in North Toraja it was abundant in the dry season. Anopheles abundance increased in Maros and North Toraja in the wet season but was more abundant in the dry season in Pasangkayu. Meanwhile, Aedes increased in the dry season in North Toraja and Pasangkayu, but in Maros, it increased in the wet season. However, on average Culex and Anopheles were found more abundant in the dry season while Aedes was abundant in the wet season.

Types of Culex and Anopheles breeding sites, e.g. river water, trenches, ponds, rice fields, in the dry season are still potential as breeding sites when filled with water and tended to be stable compared to the wet season where the amount of water will change depending on the flow of rainwater. The heavy water flow actually made the Culex and Anopheles larvae less able to survive. Other potential breeding sites in the dry season were containers around the settlement (Aedes and Armigeres), edge of swamp area (Lutzia and Mansonia), and water reservoir plants (Mimomyia). Larva Aedes which prefers breeding sites around housing, will increase in the wet season because the containers were filled with water. Few mosquitoes, such as Coquillettidia and Uranotaenia also increased in the wet season.

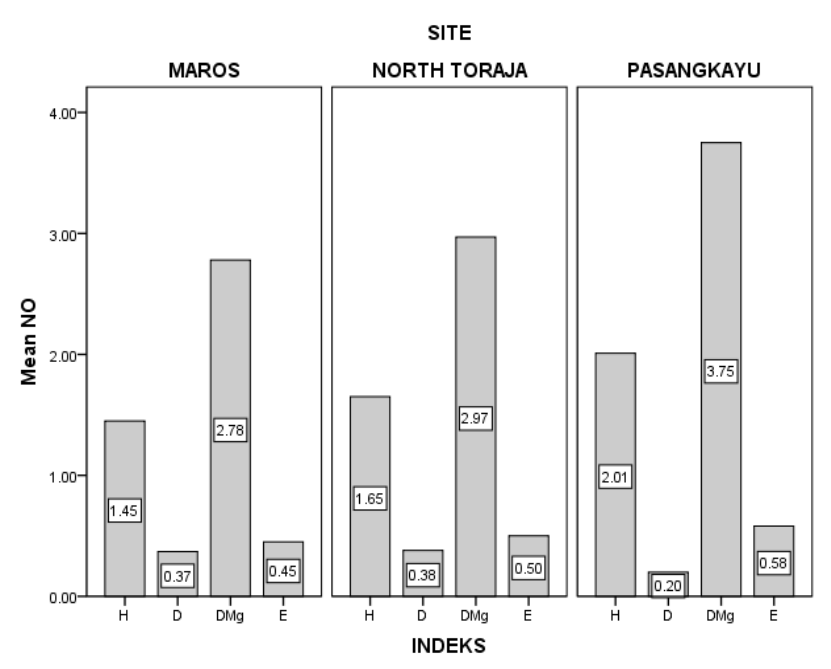

Figure 4. Index of Shannon (H), Simpson (D), Margalef (DMg) dan Evenness (E) for each site 

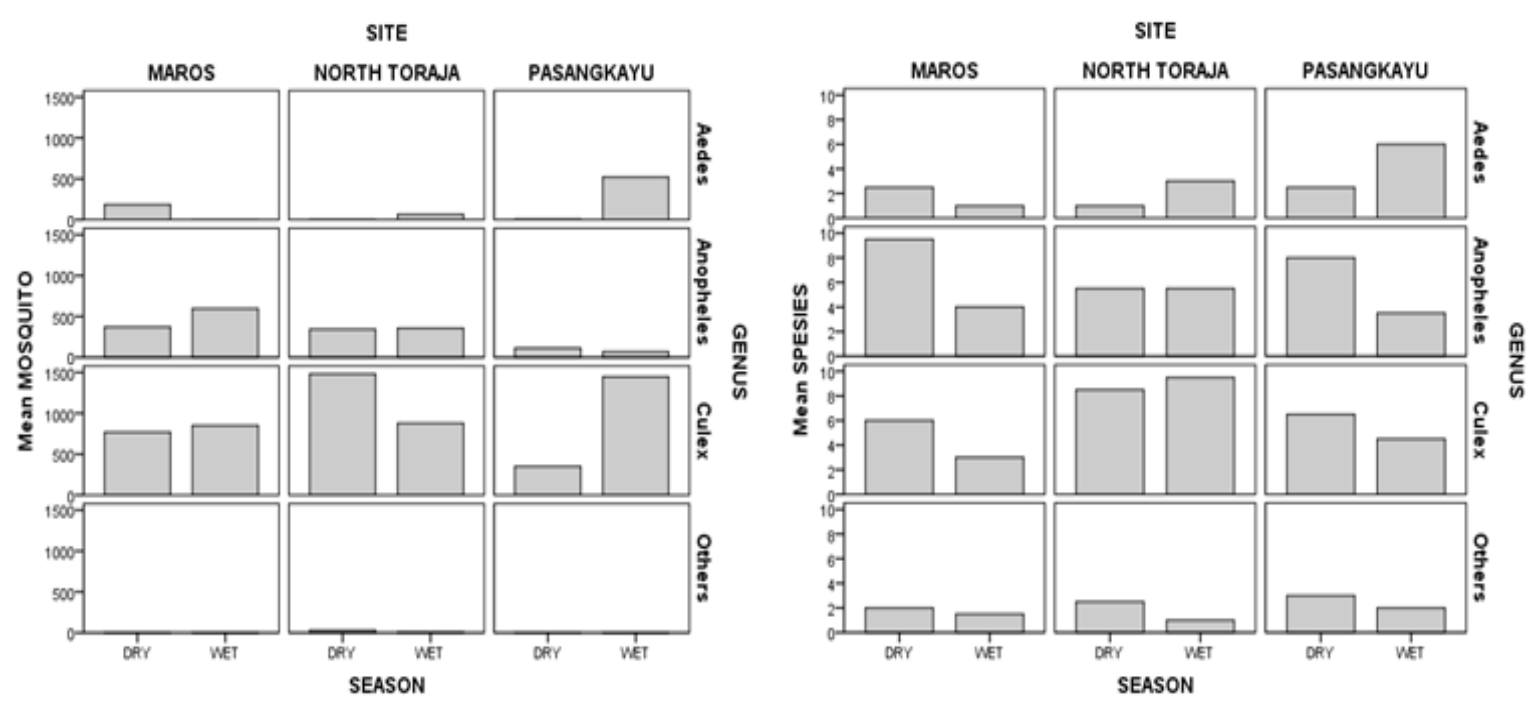

Figure 5. Proportion of the number of individual of mosquitoes (left) and number of species (right) in each season
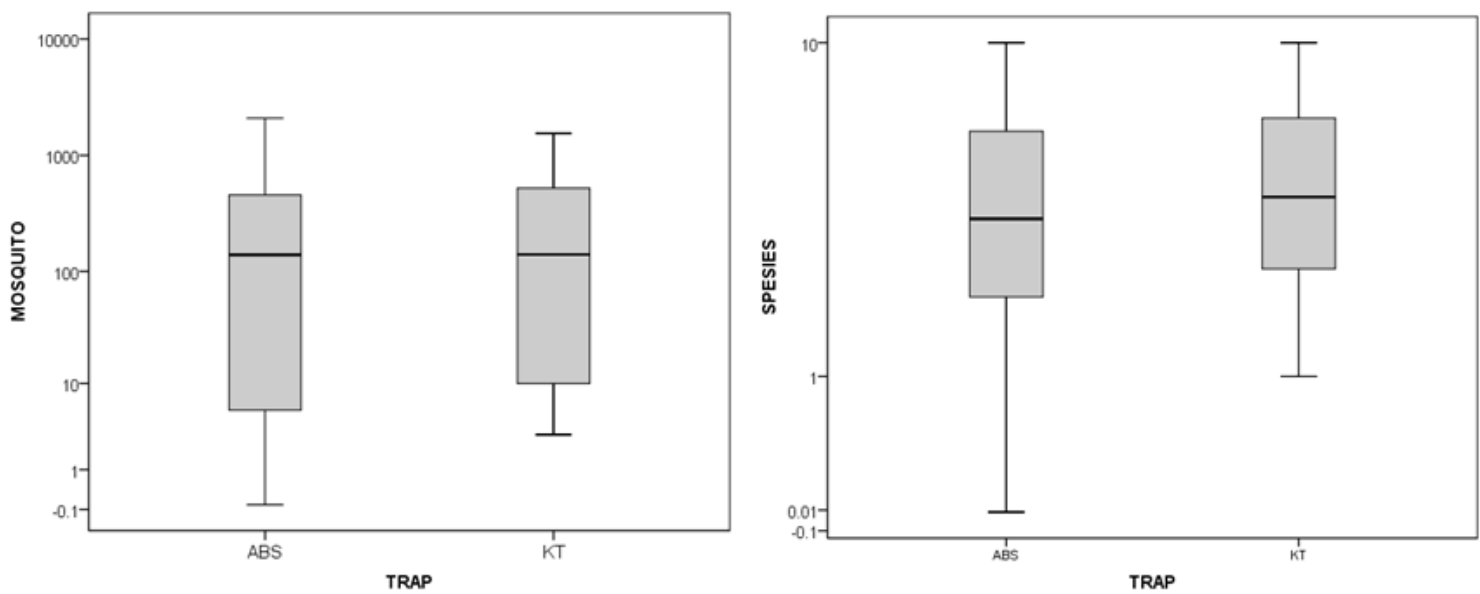

Figure 6. Trap performance in term of the trapped total number of individual mosquito (left) and number of species (right) from all site

There are various methods for catching adult mosquitoes for surveillance and study purposes. Human Landing Catches (HLC) as a gold standard is more effective in capturing adult mosquitoes compared to Ifakara tent trap (ITT) and light trap (Govella et al. 2011), BG malaria trap, and BG sentinel trap (Batista et al. 2018), Mosclean (ultraviolet LED) Trap (Mwanga et al. 2019), human-baited double net (Gao et al. 2018) and light trap (Kenea et al. 2017). However, the HLC method is less effective compared to the use of Kelambu Trap (Hajar 2016, unpublish data), barrier screens (Davidson et al. 2019), barrier screen with eaves (Davidson et al. 2019), and Animal Barrier Trap (Laurent et al. 2016). HLC can catch five species of mosquitoes while barrier screen got 14 species (Burkot et al. 2013). Davidson et al. (2019) showed that indoor and outdoor HLC obtained 2 and 3 species, respectively, while $\mathrm{BS}$ and $\mathrm{KT}$ can catch 5 and 3 species, respectively. Laurent et al. (2016) showed that HLC and
ABT could catch two and four species, respectively. Despite those performances, HLC is still recommended to use because it is very effective for mosquito research as a vector host preference.

Total individual of mosquitoes caught was higher in ABS (8589) than KT (8350), but total species were more diverse in KT (43 species 9 genera) than ABS (36 species 7 genera) (Figure 6).

Individual mosquitoes from trap in Maros and northern Toraja were higher in KT (3062 and 3761, respectively) than ABS (2504 and 2577, respectively) but in Pasangkayu more in ABS (3508) than KT (1527). In the dry and wet season, there are more mosquitoes on the ABS (3730 and 4859 , respectively) than KT (3601 and 4749, respectively) (Figure 7). The effectiveness of traps in both seasons was higher in ABS than in KT, but for number of species, there were differences in the effectiveness of traps in each season. 

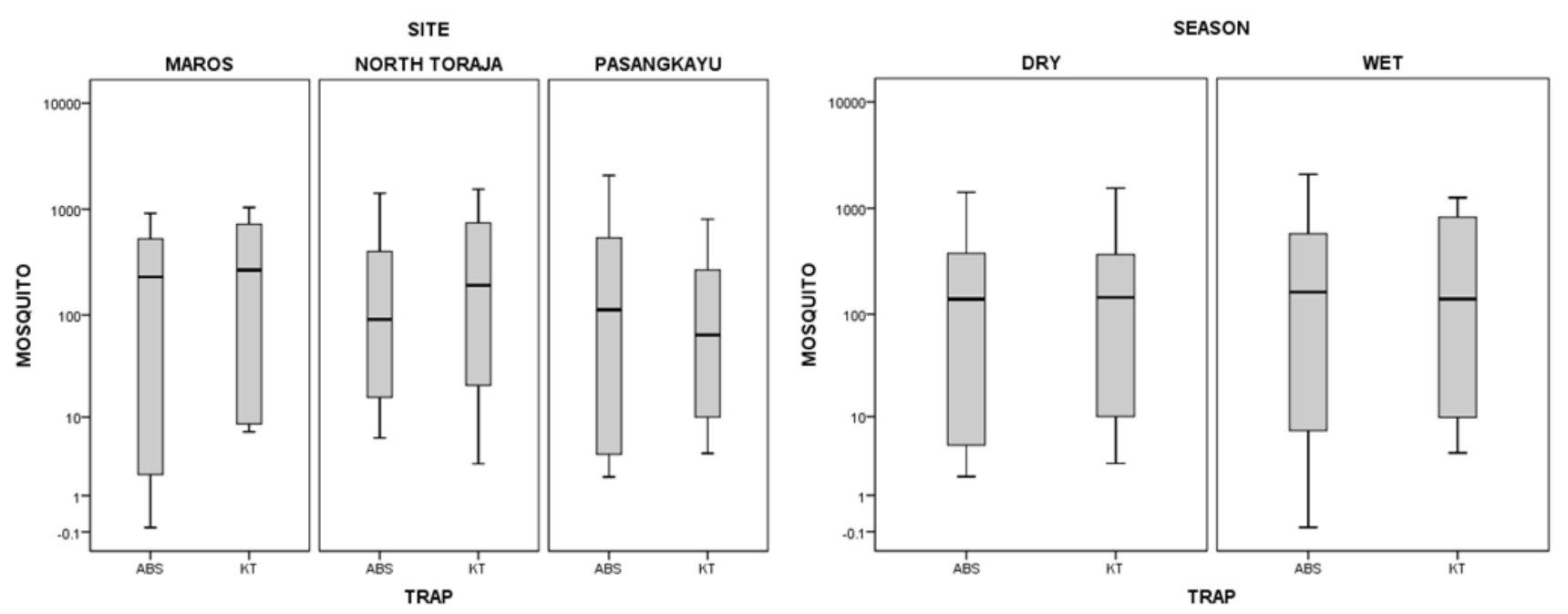

Figure 7. Trap performance in term of the trapped number of individual mosquito from each site (left) and season (right)

Table 3. Trap performance in the dry and wet season

\begin{tabular}{lcccccc}
\hline \multirow{2}{*}{ Trap } & \multicolumn{3}{c}{ Dry season } & \multicolumn{3}{c}{ Wet season } \\
\cline { 2 - 7 } & No. genera & No. species & No. individual & No. genera & No. species & No. individual \\
\hline ABS & 7 & 31 & 3730 & 5 & 27 & 4859 \\
KT & 7 & 30 & 3601 & 8 & 36 & 4749 \\
\hline
\end{tabular}

In this study, the Animal Barrier Screen (ABS) and Kelambu Trap (KT) were effective to catch mosquitoes. ABS has been shown to be more effective than KT in catching mosquitoes, but for number of species, there are differences between both traps. In the dry season, there were more species in ABS (31 species, 7 genera) than KT (30 species, 7 genera), but in wet season there were more species in KT (36 species of 8 genera) than ABS (27 species 5 genera) (Table 3 ).

The effectiveness of ABS may be caused by many mosquitoes feed on animal blood and stop at ABS, or the mosquitoes around the breeding site rested on ABS. The species of mosquito trapped depends on breeding site types around the trap or livestock blood tendencies. Kelambu Trap was placed near settlements and breeding sites; so it became an effective place for mosquito to rest, but not for mosquitoes that feed on blood. Side folded KT made mosquitoes trapped inside and difficult to exit. The index values for each trap show a nearly uniform pattern (Figure 8 ), suggesting there is no significant difference between the two traps.

The use of insecticide-treated bed nets is an effort that needs attention. A study conducted by Atieli et al. (2011) showed that the prevalence of malaria in the wet season for Insecticide-treated Net (ITN) users was 30\% lower than non-ITN. This information can be innovations on KT and ABS trap. KT and ABS insecticide can be tested by placing it in settlement and around breeding habitats so that resting adult mosquitoes will be dead and the population will decrease.
Mosquitoes are most abundant in Northern Toraja then Maros and Toraja, but species diversity is highest in Pasangkayu, then North Toraja and Maros. The most abundant mosquito in all three locations was Culex. The use of Kelambu Trap and Animal Barrier Screens was very effective for catching mosquitoes, and it can be used as innovative traps by adding insecticide to reduce adult mosquitoes in the field.

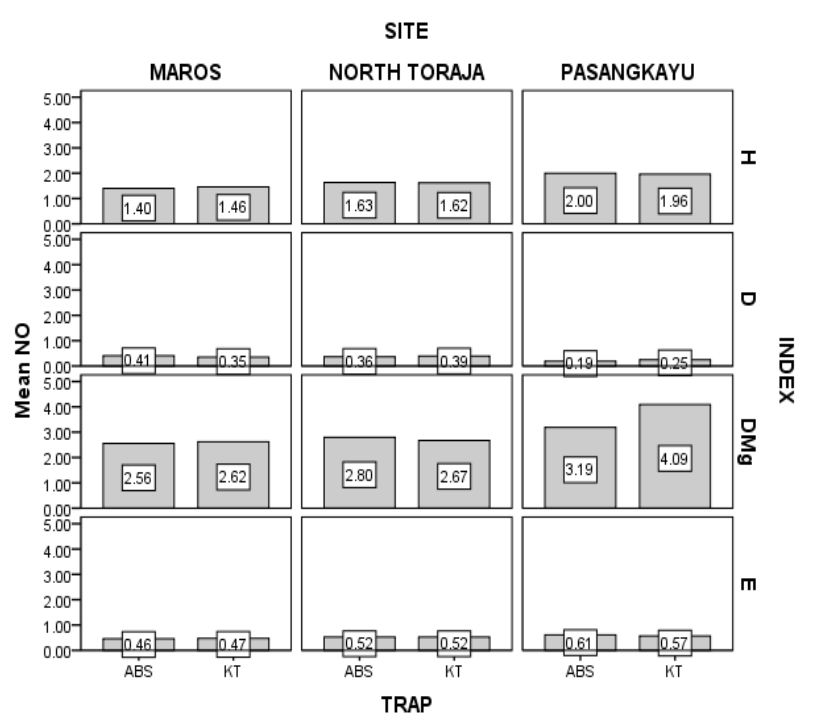

Figure 8. Index Shannon (H), Simpson (D), Margalef (DMg) dan Evenness (E) for each site and trap 


\section{ACKNOWLEDGEMENTS}

The authors wish to thank the Indonesian Ministry of Education and Culture, and Entomology and Parasitology Laboratory staff, Faculty of Medicine, Hasanuddin University, Makassar, Indonesia as well as all administrative person in the field for their support in this research.

\section{REFERENCES}

Atieli HE, Zhou G, Afrane Y, Lee M, Mwanzo I, Githeko AK. 2011 Insecticide-treated net (ITN) ownership, usage, and malaria transmission in the highlands of western Kenya. Parasites Vector 4: 110.

Batista EPA, Ngowo H, Opiyo M, Shubis GK, Meza C, Id DJS, Eiras AE, Okumu FO. 2018. Field evaluation of the BG-Malaria trap for monitoring malaria vectors in rural Tanzanian villages. PLoS One 13 1-18. DOI: DOI: 10.1371/journal.pone.0205358.

Becker N, Dušan P, Marija Z, Clive B, Minoo M, Christine D, Achiml K. 2010. Mosquitoes and Their Control. Springer, New York.

Burkot TR, Tanya LR, Lisa JR, Hugo B, Nigel WB, Robert DC, Supraman S, Frank HC, Neil FL. 2013. Barrier Screens : A method to sample blood-fed and host-seeking exophilic mosquitoes. Malaria J 12: 1-9. DOI: $10.1186 / 1475-2875-12-49$.

Contigiani, MS, Luis AD, Lorena IS. 2017. General Aspects on Arboviruses. In: Arthropod-Borne Diseases. Springer International Publishing, Switzerland.

David BJ and Tyler KL. 2016. Arbovirus Infection. HHS Pub Acc 21: 1599-1611.

Davidson JR, Isra W, Rusdiyah S, Victoria M, Hajar H, Andi MA, Nirwana N, Muhammad YH, Allison LH, Honglin X, Xiaoyu Y, Puji BSA, Din S, Neil FL. 2019. Comparative field evaluation of kelambu traps, barrier screens, and barrier screens with eaves for longitudinal surveillance of adult Anopheles mosquitoes in Sulawesi, Indonesia. Parasites Vectors 12: 1-13. DOI:10.1186/s13071-019-3649-7.

Davidson JR, Rusdiyah S, Isra W, Robert NB, Hajar H, Andi MA, Nirwana N, Muhammad YH, Din S, Neil FL. 2019. Mark-releaserecapture studies reveal preferred spatial and temporal behaviors of anopheles barbirostris in West Sulawesi, Indonesia. Parasites Vectors 12: 1-11. DOI: 10.1186/s13071-019-3640-3.

Ferede G, Tiruneh M, Abate E, Kassa WJ, Wondimeneh Y, Damtie D, Tessema B. 2018. Distribution and larval breeding habitats of Aedes mosquito species in residential areas of northwest Ethiopia. epiH 40: $1-7$.

Fros JJ, Miesen P, Vogels CB, Gaibani P, Sambri V, Martina BE, Koenraadt CJ, van Rij RP, Vlak JM, Takken W, Pijlman GP. 2015 Comparative Usutu and West Nile virus transmission potential by local Culex pipiens mosquitoes in north-western Europe. One Health 1: 31-36. DOI: 10.1016/j.onehlt.2015.08.002.

Gao Q, Wang F, Lv X, Cao H, Zhou J, Su F, Xiong C, Leng P. 2018. Comparison of the human-baited double net trap with the human landing catch for Aedes albopictus monitoring in Shanghai. Parasite Vector 11: 1-12.

Govella NJ, Chaki PP, Mpangile JM, Killeen G F. 2011. Monitoring mosquitoes in urban Dar es Salaam: Evaluation of resting boxes, window exit traps, CDC light traps, Ifakara tent traps and human landing catches. Parasites Vector 4: 9-14.

Huang YJS, Victoria BA, Amy CL, Isik U, Barry WA, Lee WC, Stephen H, Dana LV. 2016. Culex Species Mosquitoes and Zika Virus. VectBorne Zoon Dis 20: 673-676. DOI: 10.1089/vbz.2016.2058.

Huang YJS, Stephen H, Dana LV. 2019. Emergence and re-emergence of mosquito-borne arboviruses. Curr Opin Virol 34: 104-109. DOI: 10.1016/j.coviro.2019.01.001.
Huang YJS, Stephen H, Dana LV. 2019. Arbovirus-mosquito vector-host interactions and the impact on transmission and disease pathogenesis of arboviruses. Front Microb 10: 1-14.

Inunggita R, Saraswati LD, Martini. 2019. Breeding places characteristic of Anopheles mosquito in Bagelen subdistrict, Purworejo. IOP Conf Ser Earth Environ Sci 246: 012053. DOI: 10.1088/17551315/246/1/012053.

Kenea O, Meshesha B, Habte T, Teshome GM, Wakgari D, Eskindir L, Bernt L, Hans JO. 2017. Comparison of two adult mosquito sampling methods with human landing catches in South-Central Ethiopia. Malar J 16: 1-15. DOI: 10.1186/s12936-016-1668-9.

Laurent BS, Sukowati S, Puji BSA, David B, John M, Helen CM, Amirullah B, Shinta, Asik S, Michelle N, Ferdinand L, Din S, William AH, Frank HC, Neil FL. 2016. Behaviour and molecular identification of Anopheles Malaria Vectors in Jayapura District, Papua Province, Indonesia. Malaria J 15: 1-8. DOI: 10.1186/s12936016-1234-5.

Lindahl J, Chirico J, Boqvist S, Thu HTV, Magnusson U. 2012. Occurrence of Japanese encephalitis virus mosquito vectors in relation to urban pig holdings. Am J Trop Med Hyg 87 (6): 10761082. DOI: 10.4269/ajtmh.2012.12-0315.

Lwande OW, Obanda V, Lindström A, Ahlm C, Evander M, Näslund J, Bucht G. 2020. Globe-Trotting Aedes aegypti and Aedes albopictus: Risk factors for arbovirus pandemics. Vec-Born Zoon Dis 20: 71-81. DOI: 10.1089/vbz.2019.2486.

Magurran AE. 1988. Ecological Diversity and Its Measurement. Princeton University Press, New Jersey.

Mwanga EP, Ngowo HS, Mapua SA, Mmbando AS, Kaindoa EW, Kifungo K, Okumu FO. 2019. Evaluation of an ultraviolet LED trap for catching Anopheles and Culex mosquitoes in south-eastern Tanzania. Parasites Vectors 12: 1-12. DOI: 10.1186/s13071-0193673-7.

Nchoutpouen E, Talipouo A, Djiappi-Tchamen B, Djamouko-Djonkam L, Kopya E, Ngadjeu CS, Doumbe-Belisse P, Awono-Ambene P, Kekeunou S, Wondji CS, Antonio-Nkondjio C. 2019. Culex species diversity, susceptibility to insecticides and role as potential vector of Lymphatic filariasis in the city of Yaoundé, Cameroon. PLoS Neg Trop Dis 13: e0007229. DOI: 10.1371/journal.pntd.0007229.

Nurdin A, Din S, Isra W, Nur NN, Toshihiko S, Motoyoshi M. 2003. Malaria and Anopheles spp in the Villages of Salubarana and Kadaila, Mamuju District, South Sulawesi Province, Indonesia. Med J Indon 12 (4): 252-258.

Philbert A, Ijumba JN. 2013. Preferred breeding habitats of Aedes aegypti (Diptera-Culicidae ) Mosquito and its public health implications in Dar es Salaam, Tanzania. J Environ Res Manag 4: 344-351.

Ramasamy R, Surendran SN, Jude PJ, Dharshini S, Vinobaba M. 2011. Larval development of Aedes aegypti and Aedes albopictus in periurban brackish water and its implications for transmission of arboviral diseases. PLoS Neg Trop Dis 5: e0001369. DOI: 10.1371/journal.pntd.0001369.

Soegianto A. 1994. Ekologi Kuantitatif, Metode Analisis Populasi dan Komunitas. UsahaNasional, Surabaya. [Indonesian]

Schulz C, Becker SC. 2018. Mosquito-borne diseases: Implications for public health. In: Benelli G, Mehlohrn H (eds) Parasitology Research Monographs. Springer International Publishing, Germany.

Service MW. 1977. A critical review of procedures for sampling populations of adult mosquitoes. Bull Ent Res 673: 343-382.

Sibala R. 2013. Faktor resiko kejadian malaria di Kabupaten Toraja Utara. [Dissertation]. Universitas Hasanuddin, Makassar. [Indonesian]

Tangena JAA, Phoutmany T, Alexandra H, Steve WL, Paul TB. 2015. The human-baited double net trap: An alternative to human landing catches for collecting outdoor biting mosquitoes in Lao PDR. PLoS ONE 10 (9): e0138735. DOI: 10.1371/journal.pone.0138735.

Widiarti, Rima T, Tri WAG. 2014. Pendekatan molekuler konfirmasi vektor Japanese Encephalitis (JE) di Kota Surabaya Jawa Timur. Vektora 6: 73-79. [Indonesian] 